\title{
MICROFINANCE NGOS IN PAKISTAN: OUTREACH AND SUSTAINABILITY
}

\author{
HAFSA HUSSAIN ${ }^{1}$, LYBA SHAHEEN ${ }^{2}$ \& MUHAMMAD AHMAD SHAHID ${ }^{3}$ \\ ${ }^{1,3}$ Research Scholar, School of Accounting and Finance, University of Central Punjab, Lahore, Pakistan \\ ${ }^{2}$ Lecturer, Leads Business School, Lahore Leads University, Lahore, Pakistan
}

\begin{abstract}
This study investigates the tradeoff between Financial Sustainability and Outreach of microfinance NGOs in Pakistan, and to find out long term relationship among the selected variables of outreach and sustainability. To achieve this objective, three outreach indicators including Number of Active Borrowers, Percentage of Female Borrowers and Average Loan Balance per Borrower are used in addition to three Financial Sustainability indicators, including Return on Assets (ROA), Return on Equity (ROE) and Operational Self-sufficiency (OSS) ratio. Secondary data of 10 NGOs for the years 2004 to 2015 is collected from Mix Market, annual reports of NGOs, and Microfinance Annual Reports. Data is analyzed using Pearson's correlation analysis, and Johenson's Co-integration Trace Test. Augmented Dickey Fuller-ADF test is also applied to check stationarity; all variables were found stationary at level. Correlation results do not clearly indicate the tradeoff between outreach and sustainability, whereas Co-integration Trace Test indicates that in long run both outreach and sustainability variables are significantly related. This study concludes that in the MFIs (NGOs) of Pakistan, there does not exist a clear tradeoff between outreach and sustainability. Long term relationship exists among all the variables of outreach and sustainability.
\end{abstract}

KEYWORDS: Microfinance, Financial Sustainability \& Outreach

Received: Apr 21, 2018; Accepted: May 11, 2018; Published: May 31, 2018; Paper Id.: IJAFMRJUN20182

\section{INTRODUCTION}

This research is to study the relationship of outreach and sustainability of microfinance NGOs and to examine the existence of tradeoff between outreach and sustainability. This study is also about finding out the long term relationship among the representative variables of outreach and sustainability. Analysis is done using the variables, Active Borrowers, Operational Self-Sufficiency Ratio, Return on Assets, Return on Equity, Percentage of Female Borrowers and Average Loan Balance per Borrower. Total ten NGOs are selected for this study. Secondary data is collected from MIX Market on the basis of their contribution to the economy, according to Microfinance Annual Review Report 2014 (latest report).

Both poverty and poor are harsh realities of third world countries, since long time (Farooq \& Khan, 2014). Microfinance emerged as a tool to alleviate poverty in 1970s, with the aim to provide financial services to poor people shunned by banks because their savings were tiny, their loan demand was small, and they lacked loan collateral (Zeller \& Meyer, 2002).

In Pakistan, microfinance was formally started in 1980s, but did not get proper attention till 1990s; this sector remained small in its start but as it got global level reputation, it flourished since last decade and now holds significant promise (PPAF, 2012). According to Economic Survey Report of Pakistan (2015), the Microfinance sector showed 29.2 percent growth in its aggregate loan portfolio, which grew by Rs. 16.7 billion; reaching to Rs. 73.7 billion against a total of 3.3 million borrowers as of March, 2015 compared to loans worth Rs. 57 billion to 
2.9 million borrowers in the corresponding period last year.

Among the different working groups of MFIs, one group is NGOs; Non-Governmental Organization (NGO) is a term that has become widely used and accepted for referring to a legally constituted, non-governmental organization created by natural or legal persons with no participation or representation of any government (Ahmad, Chandio, \& Naseem, 2011). According to Rehman and Ismail (2012), NGOs must be voluntary, independent, not for profit and not selfserving in aims and related values.

Since last few years, a shift has been observed from social objective of poverty alleviation to financial objective of the Microfinance NGOs due to the introduction of institutional approach (Gondal, 2013). Gashayie and Singh (2014) stated that according to institutional approach it is considered that self-sufficiency of MFIs is more important whereas according to Welfarists' Approach, poor cannot afford high interest rates and hence need subsidizes. This conflict has given rise to the debate over the existance of trade-off between outreach to the poor and fianancial sustainability (Hermas \& Lensink, 2011).

According to the advocators of financial sustainability approach, there is no trade-off between outreach and financial sustainability; which means, outreach could be achieved while MFIs are financially sustainable (Nurmakhanova, Kretzschmar and Fedhila, 2014). But, advocates of Welfarists' Approach contradict the claim by advocating that there is a trade-off between financial sustainability and outreach, which claims that while targeting profitability, MFIs will focus on wealthier borrowers at the expense of poorer people, who are costly and riskier to be financially served (Hermes, Lensink and Meesters, 2008).

In Pakistan too, this conflict of opinion about the tradeoff between outreach and sustainability exists (Rauf and Mahmood, 2009). According to Gondal (2013), reasons of limited outreach and low sustainbailiy of NGOs in Pakistan are due to lack of credibility and transperancy in the system; in developed world, NGOs are run by rich donors as well as common people support their projects whereas Pakistani people are contributing significant amount towards microfinance. In general financial sustainability is serious threat to NGOs because layman's living standard itself needs to be improved. In line to this, therefore, the objective of this paper is to examine a tradeoff between outreach and sustainability and thereby to contribute to the ongoing debate on whether outreach and sustainability are substitutes or complements by focusing on Pakistani NGOs as a case. Some research is done on NGOs in Pakistan, so this study would be productive in nature for literature as well as for NGOs management.

\section{LITERATURE REVIEW}

Micro-finance has been defined by different people and institutions with their different perspectives. According to Ajmal and Qureshi (2011), microfinance refers to a provision of set of financial products to all those that are unable to get benefits by the formal financial system. Whereas, Social objectives of microfinance are defined by Almas and Mukhtar (2013) as the effective translation of an institution's social goals into practice in line with accepted social values; these include sustainably serving increasing number of poor people, improving quality, appropriateness of financial services, and improving economic and social conditions of clients. Microfinance is the provision of a broad range of financial services for low-income individuals or households (Nghiem, Coelli and Rao, 2005).

Among various types of microfiannce instituions, one type is Non-Government Organizations (NGOs) (Gondal 2013). NGOs are not only non- governmental but also nonpolitical, non- profitable and non- sectarian 
organizations with the aim to strengthen the community with the welfare relationship between citizens and workers (employee of organization) along with unpaid citizens (Ahmad, Chandio and Naseem, 2004). According to Nurmakhanova, Kretzschmar and Fedhila (2014), sustainability means delivering microfinance services to the people in a profitable manner without depending on subsidies. Sustainability refers to institution's repeatable ability to continue as a going concern by providing financial services to a wide range of clients who are disregarded by the regular financial institutions (Rao \& Fitamo, 2013). Sustainability can be explained in different aspects including organizational, financial, and environmental but issue of financial sustainability has attracted more attention (Thapa, 2009). Financial sustainability means, an institution is capable of generating sufficient revenue from offered services to meet its full operating costs (Ali, 2011).

According to Borbora and Sarma (2009), sustainability is further divided into two dimensions including Operational Self-Sufficiency (OSS) and Financial Self-Sufficiency (FSS). OSS indicates whether enough revenue has been earned to cover the MFI's direct costs, excluding the cost of capital but including any actual financing costs. Since all MFIs do not incur financial cost equally, hence for the sake of simplicity, financing cost is excluded. FSS on the other hand depicts the actual financial health of MFIs (Rao \& Fitamo, 2013). They indicated that sustainability is a mean to achieve outreach and it indicates permanency in realizing the intended goal of program. An organization must be financially self-sufficient in order to meet the requirements of their needy clients if their donors leave them because only FSS organizations could earn desirable profits. Khandker, Baqui and Khan (1995) stated that default rate could also be used as an indicator for financial sustainability.

Financial sustainability is a tangible parameter and it could be measured through different indicators including Return on Assets, Return on Equity, Operational Self-Sufficiency Ratio, Financial Self-Sufficiency Ratio, and Subsidy Dependence Index (SDI) (Rao \& Fitamo, 2013).

Outreach is considered to be the principal aim of NGOs and it needs to be achieved without sacrificing sustainability (Sathyea, Mukhopadhyayb, \& Sathyea, 2014). It can be measured according to Zeller and Meyer (2002) as: (a) the number of persons served; (b) the number of women served; (c) the proportion of the poorest of the poor served; and (d) the variety of financial services provided.

There are six dimensions of outreach including breadth, depth, scope, worth, cost and length (Nurmakhanova, Kretzschmar, \& Fedhila, 2014). Among these six dimensions, first four provide a good approximation of the extent and pattern of growth of institutions, whereas remaing two portray financial performance, efficiency and productivity of a microfinance institution (Rauf \& Mahmood, 2009). Outreach indicators include number of active borrowers, percentage of female borrowers, number of districts covered, total loan size, average loan balance per borrower / GNI per capita, average loan balance per borrower, and average loan size on outstanding portfolio (Borbora \& Sarma 2009). Farooq and Khan (2014) stated that, the successful operation of Akhuwat and Wasil Foundation like many others Islamic MFIs in Pakistan for the last more than a decade proved that Islamic microfinance institutions are viable and sustainable even in the absence of charging interest from their clients. So, the rich section of the society diverting their charity including Sadaqat, and Zakat to these microfinance institutions is enabling them to be self-sustainable.

Sathyea, Mukhopadhyayb and Sathyea (2014) found that without sacrificing ethical issues, microfinance institutions can very well achieve competing objectives of outreach and sustainability in India. Gashayie and Singh (2014) found that there is no statistically significant relationship between outreach and financial sustainability in Ethiopia. 
Kereta (2007) found that outreach of MFIs has shown increment in the recent past; it is also identified that while MFIs reach the very poor, their reach to the disadvantageous, particularly to women is limited (i.e. 38.4 Percent). From financial sustainability angle, Kereta (2007) also found that MFIs in Ethiopia are hopeful and these are operationally sustainable, measured by Return on Asset, Return on Equity, and the industry's profit performance. Kaur (2014) found that microfinance crisis has hit operationally sustainability of Indian MFIs very badly, yet, on cost front Indian MFIs seem to be best performers in South Asia. Aajmal and Qureshi (2011) concluded that microfinance institutions lack financial sustainability and very few of MFIs have attained financial sustainability as well as economies of scale; they also concluded that in Pakistan microfinance is more considered as a social service than a financial service.

\section{DATA ANALYSIS}

Data is collected from ten different working NGOs in Pakistan including Damen, Akhuwat, Asasah, Kashf Foundation, National Rural Support Program-NRSP, Orangi, Sungi, TRDP, SRSP and PRSP. Secondary data was collected from Microfinance Information Exchange-MIX website, annual reports and audit reports of the NGOs. Ten NGOs are selected on the basis of their contribution level, according to the statistics of Microfinance Annual Survey Report 2014. Tradeoff is checked though correlation analysis as done by Borbora and Sarma (2009). In this study, dimensions of sustainability considered for analysis are Operational Self-Sufficiency Ratio, Return on Assets and Return on Equity whereas for outreach, dimensions are number of Active Borrowers, Percent of Female Borrowers and Average Loan Balance per Borrower (Gashayie \& Singh 2014).

Table 1: Comparison of Average Values of Sustainability and Outreach of Microfinance NGOs in Pakistan Over Twelve Years (2004-2015)

\begin{tabular}{|l|c|c|c|c|c|c|c|c|c|c|}
\hline & Damen & Akhuwat & Asasah & Kashf & NRSP & Orangi & Sungi & TRDP & SRSP & PRSP \\
\hline ROA & 7.40 & -5.65 & -32.09 & 3.67 & 7.35 & 1.23 & 14.50 & 8.12 & 4.90 & 4.78 \\
\hline ROE & 12.84 & -4.05 & 68.07 & 29.55 & -5.53 & 10.20 & 1.33 & 30.01 & 59.08 & 1.60 \\
\hline OSS & 109.1 & 53.77 & 56.16 & 113.73 & 118.72 & 157.55 & 164.90 & 101.11 & 44.85 & 122.05 \\
\hline $\begin{array}{l}\text { Actual } \\
\text { Borrowings }\end{array}$ & 32,064 & 118,769 & 16,976 & 229,197 & 383,701 & 27,008 & 7,510 & 56,319 & 4,976 & 66,376 \\
\hline $\begin{array}{l}\text { Female } \\
\text { Borrowings (\%) }\end{array}$ & 100 & 40.90 & 99.78 & 99.83 & 61.04 & 18.68 & 83.42 & 49.96 & 77.53 & 46.44 \\
\hline $\begin{array}{l}\text { Ave.Loan } \\
\text { (USD) }\end{array}$ & 151.25 & 102.08 & 189.52 & 142.17 & 159.00 & 122.00 & 93.18 & 130.42 & 78.79 & 125.00 \\
\hline
\end{tabular}

Table 1 shows that Sungi has highest Return on Assets (ROA) over the years that are $14.50 \%$, OSS is $165 \%$ but there is low Number of Active Borrowers (i.e. 7,510 persons), Female Borrowers' Percentage is 83.42\% and Average Loan Balance per Borrower is USD 93.18. That shows Sungi is financially sustainable over the years as Operational SelfSufficiency (OSS) less than 100 per cent shows operations of MFIs are not sustainable and their unable to recover their operational costs from operational revenue (Kaur, 2014). It can also be observed that sustainability of Akhuwat, Asasah and SRSP are not enough to recover their operational costs from operational revenues. SRSP has highest Return on Equity, which is $59.08 \%$ but low Number of Active Borrowers, Female Borrowers' Percentage and Average Loan Balance per Borrower. NRSP has highest Number of Active Borrowers that is, 383,701 persons. Operational Self-Sufficiency is highest in Sungi with 164.90\%. Female Borrowers are highest in Damen, that is $100 \%$ and Average Loan per Balance is highest in Asasah, which is USD 189.52. Table 1 also highlights that Operational Self-Sufficiency Ratio (OSS) of Akhuwat, Asasah and SRSP are less than $100 \%$ that means, these three NGOs are unable to recover their operational costs from their operational revenue. 
Table 2: Correlation Analysis

\begin{tabular}{|l|c|c|c|c|c|c|}
\hline & $\begin{array}{c}\text { Active } \\
\text { Borrower }\end{array}$ & $\begin{array}{c}\text { Average Loan } \\
\text { per borrower }\end{array}$ & Female & OSS & ROA & ROE \\
\hline Number of Active Borrowers & 1.000000 & & & & & \\
\hline Average Loan per Borrowers & -0.051326 & 1.000000 & & & & \\
\hline Percentage of Female Borrowers & 0.001336 & 0.126585 & 1.000000 & & & \\
\hline OSS & 0.031150 & -0.082077 & 0.017015 & 1.000000 & & \\
\hline ROA & 0.077162 & 0.038303 & 0.013895 & 0.564083 & 1.000000 & \\
\hline ROE & -0.076106 & 0.006611 & 0.052636 & -0.012380 & 0.218646 & 1.000000 \\
\hline
\end{tabular}

In order to identify the relationship between selected variables, this study employed correlation analysis. Table 2 shows the relationship between Active Borrower (outreach) and Return on Equity (sustainability) that is 0.076106, which means, increase in Return on Equity decreases the Number of Active Borrowers. Relationship between Average Loan per Borrower (outreach) and Operational Self-Sufficiency (sustainability) is negative, that is -0.082077 . This means, as the Average Loan per Borrower increases, operational sustainability of NGOs decreases.

Long term relationship among the variables is checked using Johenson's Co-integration. Six models are applied using first each variable of outreach as dependent variable and other three variables of sustainability as independent and then each variable of sustainability as dependent variable and other three variables of outreach as independent variables. The following are the results of co-integration. In all these tables ' $*$ ' denotes rejection of the hypothesis at 0.05 level and ‘**' is MacKinnon-Haug-Michelis (1999) p-values.

Results of Augmented Dickey Fuller-ADF Tests show stationarity in all the variables. Null hypothesis of ADF is that the data has unit root. Lag length is zero and exogenous variable is the Constant in each equation. In ADF Test Equations Least Square method is used.

\section{ADF: Operational Self-Sufficiency-OSS}

\begin{tabular}{|c|c|c|c|c|}
\hline & & & t-Statistic & Prob.* \\
\hline \multicolumn{3}{|c|}{ Augmented Dickey-Fuller Test Statistic } & -3.873150 & 0.0030 \\
\hline \multirow[t]{3}{*}{ Test critical values } & $1 \%$ level & & -3.486064 & \\
\hline & $5 \%$ level & & -2.885863 & \\
\hline & $10 \%$ level & & -2.579818 & \\
\hline \multicolumn{4}{|c|}{ Augmented Dickey-Fuller Test Equation } & \\
\hline \multicolumn{3}{|c|}{ Dependent Variable: D(OSS) } & & \\
\hline Variable & Coefficient & Std. Error & t-Statistic & Prob. \\
\hline OSS $(-1)$ & -0.235777 & 0.060875 & -3.873150 & 0.0002 \\
\hline $\mathrm{C}$ & 0.252516 & 0.071636 & 3.524976 & 0.0006 \\
\hline
\end{tabular}

ADF: Return on Equity-ROE

\begin{tabular}{|c|c|c|c|c|}
\hline & & & t-Statistic & Prob.* \\
\hline \multicolumn{3}{|c|}{ Augmented Dickey-Fuller Test Statistic } & -9.482462 & 0.0000 \\
\hline \multirow[t]{3}{*}{ Test Critical Values } & $1 \%$ level & & -3.486064 & \\
\hline & $5 \%$ level & & -2.885863 & \\
\hline & $10 \%$ level & & -2.579818 & \\
\hline \multicolumn{4}{|c|}{ Augmented Dickey-Fuller Test Equation } & \\
\hline \multicolumn{3}{|c|}{ Dependent Variable: $\mathrm{D}(\mathrm{ROE})$} & & \\
\hline Variable & Coefficient & Std. Error & t-Statistic & Prob. \\
\hline ROE(-1) & -0.868942 & 0.091637 & -9.482462 & 0.0000 \\
\hline $\mathrm{C}$ & 0.250282 & 0.179643 & 1.393218 & 0.1662 \\
\hline
\end{tabular}


ADF: Return on Assets-ROA

\begin{tabular}{|c|c|c|c|c|}
\hline & & & t-Statistic & Prob.* \\
\hline \multicolumn{3}{|c|}{ Augmented Dickey-Fuller test statistic } & -7.374461 & 0.0000 \\
\hline \multirow[t]{3}{*}{ Test critical values: } & $1 \%$ level & & -3.486064 & \\
\hline & $5 \%$ level & & -2.885863 & \\
\hline & $10 \%$ level & & -2.579818 & \\
\hline \multicolumn{3}{|c|}{$\begin{array}{c}\text { Augmented Dickey-Fuller Test Equation } \\
\text { Dependent Variable: D(ROA) }\end{array}$} & & \\
\hline Variable & Coefficient & Std. Error & t-Statistic & Prob. \\
\hline $\mathrm{ROA}(-1)$ & -0.635760 & 0.086211 & -7.374461 & 0.0000 \\
\hline $\mathrm{C}$ & -0.030994 & 0.016687 & -1.857338 & 0.0658 \\
\hline
\end{tabular}

\section{ADF: Percentage of Female Borrowers-POFB}

\begin{tabular}{|c|c|c|c|c|}
\hline & & & t-Statistic & Prob.* \\
\hline \multicolumn{3}{|c|}{ Augmented Dickey-Fuller test statistic } & -3.111595 & 0.0283 \\
\hline \multirow[t]{3}{*}{ Test critical values: } & $1 \%$ level & & -3.486064 & \\
\hline & $5 \%$ level & & -2.885863 & \\
\hline & $10 \%$ level & & -2.579818 & \\
\hline \multicolumn{4}{|c|}{ Augmented Dickey-Fuller Test Equation } & \\
\hline \multicolumn{3}{|c|}{ Dependent Variable: D(POFB) } & & \\
\hline Variable & Coefficient & Std. Error & t-Statistic & Prob. \\
\hline POFB(-1) & -0.149987 & 0.048203 & -3.111595 & 0.0023 \\
\hline $\mathrm{C}$ & 0.097366 & 0.036008 & 2.704029 & 0.0079 \\
\hline
\end{tabular}

ADF: Number of Active Borrowers-NOAB

\begin{tabular}{|c|c|c|c|c|}
\hline & & & t-Statistic & Prob.* \\
\hline \multicolumn{3}{|c|}{ Augmented Dickey-Fuller test statistic } & -3.799484 & 0.0038 \\
\hline \multirow[t]{3}{*}{ Test critical values: } & $1 \%$ level & & -3.486064 & \\
\hline & $5 \%$ level & & -2.885863 & \\
\hline & $10 \%$ level & & -2.579818 & \\
\hline \multicolumn{4}{|c|}{ Augmented Dickey-Fuller Test Equation } & \\
\hline \multicolumn{3}{|c|}{ Dependent Variable: D(NOAB) } & & \\
\hline Variable & Coefficient & Std. Error & t-Statistic & Prob. \\
\hline $\operatorname{NOAB}(-1)$ & -0.218138 & 0.057412 & -3.799484 & 0.0002 \\
\hline $\mathrm{C}$ & 21100.09 & 9535.041 & 2.212899 & 0.0288 \\
\hline
\end{tabular}

ADF: Average Loan per Borrower-ALPB

\begin{tabular}{|l|l|l|l|l|}
\hline & & & t-Statistic & Prob.* \\
\hline \multicolumn{2}{|c|}{ Augmented Dickey-Fuller test statistic } & $\mathbf{- 7 . 1 7 8 7 2 6}$ & $\mathbf{0 . 0 0 0 0}$ \\
\hline Test critical values: & $1 \%$ level & & -3.486064 & \\
\hline & $5 \%$ level & & -2.885863 & \\
\hline & $10 \%$ level & & -2.579818 & \\
\hline Variable & Coefficient & Std. Error & t-Statistic & Prob. \\
\hline ALPB(-1) & -0.611455 & 0.085176 & -7.178726 & 0.0000 \\
\hline C & 141.2371 & 77.38223 & 1.825188 & 0.0705 \\
\hline
\end{tabular}

Johenson's Co-integration is applied to find out long term relationship among the six variables of the study. Table 3, 4 and 5 show the long term relationship of independent variables of outreach with the dependent variables of sustainability (i.e. ROA, ROE and OSS). 
Table 3: Unrestricted Co Integration Rank Test (Trace)

\begin{tabular}{|c|c|c|c|c|}
\hline \multicolumn{5}{|c|}{$\begin{array}{c}\text { Trend Assumption: Linear Deterministic Trend } \\
\text { Series: ROA POFB ALPB NOAB } \\
\text { Lags Interval (in First Differences): } 1 \text { to } 4\end{array}$} \\
\hline Hypothesized & & Trace & 0.05 & \\
\hline No. of CE(s) & Eigen Value & Statistic & Critical Value & Prob.** \\
\hline None $*$ & 0.267100 & 76.01353 & 47.85613 & 0.0000 \\
\hline At most $1 *$ & 0.192370 & 40.27770 & 29.79707 & 0.0022 \\
\hline At most $2 *$ & 0.072573 & 15.70785 & 15.49471 & 0.0464 \\
\hline At most $3 *$ & 0.059411 & 7.043616 & 3.841466 & 0.0080 \\
\hline
\end{tabular}

Table 4: Unrestricted Co-integration Rank Test (Trace)

\begin{tabular}{|c|c|c|c|c|}
\hline \multicolumn{5}{|c|}{$\begin{array}{c}\text { Trend Assumption: Linear Deterministic Trend } \\
\text { Series: ROE POFB NOAB ALBB } \\
\text { Lags Interval (in First Differences): } 1 \text { to } 4\end{array}$} \\
\hline Hypothesized & & Trace & 0.05 & \\
\hline No. of CE(s) & Eigen Value & Statistic & Critical Value & Prob.** \\
\hline None $*$ & 0.241959 & 73.58136 & 47.85613 & 0.0000 \\
\hline At most $1 *$ & 0.193184 & 41.72428 & 29.79707 & 0.0014 \\
\hline At most $2 *$ & 0.085295 & 17.03842 & 15.49471 & 0.0291 \\
\hline At most $3 *$ & 0.057300 & 6.785785 & 3.841466 & 0.0092 \\
\hline
\end{tabular}

Table 5: Unrestricted Co-integration Rank Test (Trace)

\begin{tabular}{|c|c|c|c|c|}
\hline \multicolumn{5}{|c|}{ Trend Assumption: Linear Deterministic Trend } \\
Series: OSS POFB NOAB ALBB \\
Lags Interval (in First Differences): 1 to 4 \\
\hline Hypothesized & & Trace & 0.05 & \\
\hline No. of CE(s) & Eigen Value & Statistic & Critical Value & Prob.** \\
\hline None * & 0.210858 & 59.63947 & 47.85613 & 0.0027 \\
\hline At most 1 & 0.124612 & 32.40646 & 29.79707 & 0.0245 \\
\hline At most 2* & 0.083386 & 17.10129 & 15.49471 & 0.0284 \\
\hline At most 3 $*$ & 0.059777 & 7.088366 & 3.841466 & 0.0078 \\
\hline
\end{tabular}

In Table 3, 4 and 5 of Trace Test, it is indicated that there are four co-integrating equations at 0.05 level of significance. In Table 3 Return on Assets-ROA is the dependent variable and Percentage of Female Borrowers-POFB, Average Loan per Borrower-ALPB and Number of Active Borrowers-NOAB are the independent variables. In Table 4 and 5, Return on Equity-ROE and Operational Self-Sufficiency-OSS are the dependent variables, respectively with the same independent variables as in Table 3.

Table 6: Unrestricted Co-integration Rank Test (Trace)

\begin{tabular}{|c|c|c|c|c|}
\hline \multicolumn{5}{|c|}{ Trend Assumption: Linear Deterministic Trend } \\
Series: POFB ROA ROE OSS \\
Lags Interval (in First Differences): 1 to 4 \\
\hline Hypothesized & & Trace & 0.05 & \\
\hline No. of CE(s) & Eigen Value & Statistic & Critical Value & Prob.** \\
\hline None * & 0.333841 & 89.24654 & 47.85613 & 0.0000 \\
\hline At most 1 $*$ & 0.199699 & 42.53039 & 29.79707 & 0.0010 \\
\hline At most 2 $*$ & 0.082722 & 16.91207 & 15.49471 & 0.0304 \\
\hline At most 3 $*$ & 0.058910 & 6.982438 & 3.841466 & 0.0082 \\
\hline
\end{tabular}


Table 7: Unrestricted Co-integration Rank Test (Trace)

\begin{tabular}{|l|c|c|c|c|}
\hline \multicolumn{5}{|c|}{ Trend Assumption: Linear Deterministic Trend } \\
Series: ALPB ROA ROE OSS \\
Lags Interval (in First Differences): 1 to 4 \\
\hline Hypothesized & & Trace & 0.05 & \\
\hline No. of CE(s) & Eigenvalue & Statistic & Critical Value & Prob.** \\
\hline None $*$ & 0.344368 & 98.68746 & 47.85613 & 0.0000 \\
\hline At most 1 $*$ & 0.211943 & 50.13957 & 29.79707 & 0.0001 \\
\hline At most 2 $*$ & 0.123405 & 22.74829 & 15.49471 & 0.0034 \\
\hline At most 3 $*$ & 0.063963 & 7.601580 & 3.841466 & 0.0058 \\
\hline
\end{tabular}

Table 8: Unrestricted Co-integration Rank Test (Trace)

\begin{tabular}{|c|c|c|c|c|}
\hline \multicolumn{5}{|c|}{$\begin{array}{l}\text { Trend Assumption: Linear Deterministic Trend } \\
\text { Series: NOAB ROA ROE OSS } \\
\text { Lags Interval (in First Differences): } 1 \text { to } 4\end{array}$} \\
\hline Hypothesized & & Trace & 0.05 & \\
\hline No. of CE(s) & Eigen Value & Statistic & Critical Value & Prob.** \\
\hline None $*$ & 0.391269 & 93.75540 & 47.85613 & 0.0000 \\
\hline At most $1 *$ & 0.166987 & 36.67191 & 29.79707 & 0.0069 \\
\hline At most $2 *$ & 0.075315 & 15.66069 & 15.49471 & 0.0472 \\
\hline At most $3 *$ & 0.056234 & 6.655885 & 3.841466 & 0.0099 \\
\hline
\end{tabular}

Table 6, 7 and 8 of Trace Test indicate that there are four co-integrating equations at 0.05 level of significance. In Table 6, Percentage of Female Borrowers-POFB is the dependent variable and Return on Assets-ROA, Return on Equity-ROE, and Operational Self-Sufficiency is the independent variables. In Table 7 and 8, Average Loan per BorrowerALPB and Number of Active Borrowers-NOAB are the dependent variables, respectively with the same independent variables as in Table 6.

\section{CONCLUSIONS}

This research is conducted to investigate the existence of tradeoff and relationship between sustainability and outreach of microfinance NGOs in Pakistan, and to check long term relationship among the variables of outreach and sustainability. The results do not clearly indicate the existence of tradeoff between outreach and sustainability, although there is negative correlation among some selected variables of the two areas. It is concluded that, there does not exist clear tradeoff between sustainability and outreach of selected microfinance NGOs in Pakistan. Increasing the outreach of these NGOs is not likely to affect their profitability, and hence their sustainability. These results are partially not in line with those of some other researchers but have theoretical support. Kaur (2014) found negative relationship between ROE and Number of Active Borrowers.

As there are two theoretical views about Microfinance Institutions regarding outreach and sustainability relationship, this study concludes that tradeoff between outreach and sustainability only partially exists and none of the two views are clearly supported. The current research, thus contributes to the literature on the relationship that there exists significant long term relationship between each selected variable of sustainability and outreach, as supported by the Trace values of these variables. 


\section{REFERENCES}

1. Aajmal, H., \& Qureshi, T. (2011). Microfinance and sustainable development: Evidence from Pakistan. Paradigms: A Research Journal of Commerce, Economics and Social Sciences, 5(1), 88-113.

2. Ahmad, M., Chandio, A. A., \& Naseem, F. (2011). Human rights and non-governmental organizations: A case study. Berkeley Journal of Social Sciences, 1(4), 226-245.

3. Ahmed, M. A., Ahmad, Z., \& Khan, A. A. (2014). Performance analysis of microfinance institution of India. Paradigms: A Research Journal of Commerce, Economics And Social Sciences, 8(1), 1-12.

4. Akhter, D., Akhtar, D., \& Jafferi, S. K. (2009). Islamic Microfinance and poverty alleviation: A case study of Pakistan. CBRC (pp. 832-890). Lahore: CBRC.

5. Ali, K. H. (2011). The relationship between financial sustainability and outreach of microfinance institutions in Kenya. Newyork: Newyork Time Press.

6. Almas, H., \& Mukhtar, M. (2013). Measuring the performance and achievement of microfinance institutions incorporating Subsidy Dependence Index and Outreach Index in Pakistan's case. Internaltional Journal of Social Sciences, 59-73.

7. Borbora, S., \& Sarma, G. K. (2009). Microfinance institutions: Sustainability and outreach. Indian Institute of Technology Guwahati, 52-63.

8. Farooq, D. M., \& Khan, Z. (2014). The social and financial performance of conventional and Islamic microfinance institutions in Pakistan. Al-Idah, 90-109.

9. Farooq, D. M., \& Khan, Z. (2014). The social and financial performance of Conventional and Islamic microfinance institutions in Pakistan. Internaltional Journal of Social Sciences, 34-56.

10. Gashayie, A., \& Singh, M. (2014). Relationship of financial sustainability and outreach in Ethiopian microfinance institutions: Empirical evidence. Research Journal of Finance and Accounting, 106-112.

11. Gondal, I. A. (2013). Role of NGO's in Pakistan: An overview. AL-ADWA, 45-63.

12. Hameed-ur-Rehman, \& Ismail, M. (2012). Study on the role of non govenrment organizations in imparting primary education in Pakistan. Interdisciplinary Journal of Contemporary Research In Business, 245-263.

13. Hermas, N., \& Lensink, R. (2011). Microfinance: Its impact, outreach, and sustainability. World Development, 39(6), 875-881.

14. Hermes, N., Lensink, R., \& Meesters, A. (2008). Outreach and efficiency of microfinance institutions. Center For International Banking, Insurance and Finance, 39(6), 938-948.

15. Kaur, P. (2014). Outreach and sustainability of microfinance institutions in India in pre and post Andhra Pradesh microfinance crisis in context of South Asia. Global Journal of Finance and Management., 6(6), 569-574.

16. Kaur, R. (2014). Outreach of microfinance in India. IOSR Journal of Business and Management, 222-232.

17. Kereta, B. B. (2007). Outreach and financial performance analysis of microfinance institutions in Ethiopia. African Economic Conference (pp. 301-332). Addis Ababa, Eithopia: United Nations Conference Center.

18. Ministry of Finance. (2015). Pakistan Economic Survey. Islamabad: Govenrmant of Pakistan.

19. Mustafa, K., Gill, Z. A., Azid, T., \& Khan, N. Z. (2014). NGOs, micro-finance and poverty alleviation: Experience of the rural poor in Pakistan. Pakistan Development Review, 39(4), 771-792. 
20. Nghiem, H. S., Coelli, T., \& Rao, P. (2005). The efficiency of microfinance in Veitnam: Evidence from NGOs schemes in the North and Central regions. International Journal of Accounting and Finance, 109-121.

21. Nurmakhanova, M., Kretzschmar, G., \& Fedhila, H. (2014). Trade-off between financial sustainability and outreach of microfinance institutions. Eurasia Business and Economics Society, 450-470.

22. PPAF. (2012). Village Banking in Pakistan. Islamabad: Pakistan Poverty Alleviation Fund.

23. Rao, P. K., \& Fitamo, T. L. (2013). Concepts and measures of outreach and sustainability in microfinance institutions. International Journal of Science and Research (IJSR), 88-85.

24. Rauf, S. A., \& Mahmood, T. (2009). Growth and performance of microfinance in Pakistan. Pakistan Economic and Social Review, 99-122.

25. Sathyea, M., Mukhopadhyayb, B., \& Sathyea, S. (2014). Sustainability and outreach in microfinance institutions in India: An ethical analysis. Canadian Journal of Development Studies, 103-123.

26. Thapa, G. (2009). Sustainability and governance of microfinance institutions: Recent experiences and some lessons for Southeast Asia. Asian Journal of Agriculture and Development, IV, 43-60.

27. Zeller, M., \& L.Meyer, R. (2002). The triangle of micro finance. Washington, D.C: The Johns Hopkins University Press. 